\title{
TINGKAT KEPUASAN PEMOHON PENSERTIFIKATAN TANAH PADA KANTOR PERTANAHAN
}

\author{
Amrieh Samad Soemarga $^{1^{*}}$, Aida Vitayala Hubeis ${ }^{2}$, Noer Azam Achsani² \\ ${ }^{1}$ Kantor Kementerian Agraria dan Tata Ruang/Badan Pertanahan Nasional, Jakarta Selatan 12014, Indonesia \\ 2Sekolah Pascasarjana Manajemen dan Bisnis, Institut Pertanian Bogor, Bogor 16680, Indonesia
}

*) E-mail: dr.samad.soemarga1959@gmail.com

\begin{abstract}
Abstrak
Layanan pertanahan mempunyai arti strategis bagi kepentingan masyarakat terutama dalam rangka memberikan jaminan kepastian hukum dan perlindungan hukum atas suatu bidang tanah sehingga masyarakat mengharapkan pelayanan pertanahan dapat diakses secara mudah, murah, cepat, dan memberi kepuasan kepada pengguna layanan tersebut. Penelitian ini bertujuan untuk menganalisis tingkat kepuasan pemohon, indikator-indikator prioritas untuk meningkatkan kepuasan pemohon, dan kebijakan yang harus ditempuh untuk meningkatkan kepuasan pemohon terhadap kualitas pelayanan pertanahan pada Kantor Pertanahan Kabupaten Badung. Penelitian dilakukan menggunakan desain cross sectional dengan metode survei pada 120 pemohon peralihan hak jual beli dan hak tanggungan dalam bentuk kuesioner. Kuesioner kemudian diolah dengan analisis uji validitas dan reliabilitas, analisis kesenjangan, dan analisis Importance Perfomance Analysis (IPA). Hasil penelitian menunjukkan bahwa kualitas pelayanan yang disediakan oleh Kantor Pertanahan Kabupaten Badung belum memenuhi kepuasan masyarakat di Kabupaten Badung, dan indikator yang perlu diprioritaskan untuk meningkatkan kepuasan pemohon adalah ketepatan waktu penyelesaian sertifikat. Jadi kebijakan alternatif yang bisa direkomendasikan dalam rangka meningkatkan kepuasan masyarakat terhadap kualitas pelayanan pensertifikatan tanah pada Kantor Pertanahan Kabupaten Badung adalah melakukan evaluasi kualitas pelayanan pensertifikatan tanah berdasarkan tingkat kualitas pelayanan yang mendapatkan prioritas untuk diperbaiki kualitas pelayanannya, agar pelayanan yang diberikan kepada masyarakat dapat lebih baik dari pelayanan sebelumnya.
\end{abstract}

Kata kunci: analisis kesenjangan, Importance Perfomance Analysis (IPA), kepuasan pemohon, pelayanan pertanahan,

\section{Satisfaction Level of Land Certification Applicant on Land Office}

\begin{abstract}
Land Service has strategic significance for the benefit of society, especially in order to provide legal certainty and legal protection of a plot so that the public expects land services are easily accessible, cheap, fast, and give satisfaction to the users of the service. This study aimed to analyze the satisfaction level of the applicant, priority indicators to improve the satisfaction level of applicant, and the policies that must be taken to improve the satisfaction level of applicant to the quality of land services in Land Office of Badung District. The study was conducted using a cross sectional survey method on 120 applicants who transferred purchase and mortgage rights in the form of a questionnaire. The questionnaire is then processed with the validity and reliability analysis, gap analysis, and analysis of Importance Performance Analysis (IPA). The results showed that the quality of services provided by Land Office of Badung District did not meet the community satisfaction in Badung, and indicators that need to be prioritized to improve the satisfaction level of applicant is the timeliness of certificate completion. So the alternative policy that can be recommended in order to improve community satisfaction on quality service of land certification in Land Office of Badung District is to evaluate the service quality of land certification. Service quality was the first priority that has to be improved based on the result of this study in order to increase the quality of public services in the future.
\end{abstract}

Keywords: applicant satisfaction, gap analysis, land services, Importance Performance Analysis (IPA)

\section{PENDAHULUAN}

Layanan pertanahan memiliki arti strategis bagi kepentingan masyarakat terutama dalam rangka memberikan jaminan kepastian hukum dan perlindungan hukum atas suatu bidang tanah. Masyarakat mengharapkan pelayanan pertanahan dapat diakses secara mudah, murah, cepat, dan memberi kepuasan kepada pengguna layanan tersebut. Namun seringkali kualitas layanan publik yang diberikan oleh pemerintah selama ini sebagian besar masih 
belum sesuai dengan yang diharapkan masyarakat (Sukirno, Mulyanto, \& Hakim, 2015).

Kesenjangan antara persepsi masyarakat mengenai kualitas pelayanan pertanahan dengan kualitas pelayanan yang sebenarnya diharapkan oleh masyarakat yang menyebabkan adanya perasaan puas atau tidak puas dari masyarakat (Arief, 2007). Persepsi masyarakat yang menyatakan puas jika kualitas pelayanan pertanahan yang diberikan sesuai dengan harapannya. Namun jika persepsi masyarakat di bawah harapan yang sesungguhnya berarti masyarakat tidak puas dengan pelayanan yang diberikan.

Hasil survei Indeks Integritas Sektor Publik Tahun 2013 yang dipublikasikan Komisi Pemberantasan Korupsi (KPK) diperoleh ratarata total indeks integritas Badan Pertanahan Nasional (BPN) adalah 6,36 dari skala 0-10 dan standar minimal yang ditetapkan sebesar 6,00. Artinya, masyarakat puas terhadap kinerja pelayanan Badan Pertanahan Nasional secara umum. Namun demikian, integritas kinerja BPN harus terus ditingkatkan dalam melayani masyarakat.

Peningkatan layanan pertanahan yang berkualitas dan berdasarkan keadilan oleh Badan Pertanahan Nasional (BPN) masih merupakan salah satu tuntutan masyarakat. Hal ini ditandai oleh keluhan masyarakat mengenai prosedur pengurusan dalam bidang pertanahan yang panjang dan berbelit-belit, serta mahalnya biaya yang harus dibayar. Sukirno, Mulyanto dan Hakim (2015) telah meneliti kepuasan masyarakat terhadap kinerja pelayanan pertanahan di Kantor Pertanahan Kota Bekasi dengan menggunakan teknik pengambilan contoh convenience sampling dan teknik analisis kesenjangan Importance Performance Analysis (IPA). Kajian tersebut menghasilkan keseluruhan kualitas pelayanan pendaftaran tanah yang diberikan oleh Kantor Pertanahan Kota Bekasi belum memenuhi kepuasan masyarakat dengan selisih rata-rata kinerja dan harapan sebesar -0,55.

Namun demikian, secara yuridis formal, kepuasan masyarakat yang menggunakan layanan pertanahan telah diakomodasi dalam peraturan perundangan yang memangkas prosedur yang bertele-tele dan panjang tersebut sebagai wujud komitmen BPN untuk memberikan kepastian dalam hal waktu dan biaya pelayanan. Perubahan kebijakan dalam memberikan pelayanan kepada masyarakat sangat diharapkan agar pelayanan pertanahan dapat diakses secara mudah, murah, cepat, dan memberikan kepuasan kepada masyarakat luas.

Musanto (2004) mendefinisikan bahwa pelayanan adalah suatu jenis kegiatan atau urutan kegiatan yang terjadi dalam interaksi langsung antara seseorang dengan orang lain atau mesin secara fisik atau nonfisik, dan menyediakan kepuasan pelanggan. Pelayanan sangat erat hubungannya dengan kehidupan manusia, bahkan secara ekstrim dapat dikatakan bahwa pelayanan tidak dapat dipisahkan dengan kehidupan manusia. Adapun ukuran keberhasilan penyelenggaraan pelayanan ditentukan oleh tingkat kepuasan penerima pelayanan (Ratminto \& Winarsih, 2006). Kepuasan penerima pelayanan dicapai apabila penerima pelayanan memperoleh pelayanan sesuai dengan yang dibutuhkan dan diharapkan.

Badan Pertanahan Nasional Republik Indonesia (BPN RI) sebagai salah satu penyelenggara pelayanan publik di bidang pertanahan bertugas memberikan pelayanan kepada masyarakat sebagai pengguna layanan dengan menggunakan standar pelayanan yang telah dibakukan sebagai pedoman pemberian layanan di bidang pertanahan. Standar pelayanan ini merupakan ukuran yang telah ditentukan sebagai suatu pembakuan pelayanan yang baik dan telah ditetapkan dalam bentuk instrumen kebijakan di bidang pertanahan (Suharno, 2002). Secara teoritis, standar pelayanan yang diterapkan dengan baik akan memberikan kepuasaan kepada masyarakat sebagai penerima pelayanan (Widjaja, Wijaya, \& Jokom, 2007). Namun demikian, kepuasan masyarakat menjadi agenda utama yang harus ditingkatkan di lingkungan BPN RI (termasuk Kantor Pertanahan Kabupaten Badung). Sejalan dengan indeks integritas BPN RI yang hanya mencapai 6,36 (skala 10) berdasarkan hasil Survei Indeks Integritas Sektor Publik Tahun 2013 yang dipublikasikan oleh Komisi Pemberantasan Korupsi. Selain menunjukkan ketidakpuasan masyarakat terhadap layanan pertanahan, indeks ini juga menunjukkan bahwa kualitas pelayanan pertanahan yang diberikan oleh BPN RI perlu diperbaiki.

Tujuan yang ingin dicapai dalam penelitian ini adalah sebagai berikut: (1) menganalisis tingkat kepuasan pemohon terhadap kualitas pelayanan pertanahan pada Kantor Pertanahan Kabupaten Badung, (2) menganalisis indikatorindikator yang perlu diprioritaskan untuk meningkatkan kepuasan pemohon terhadap 
kualitas pelayanan pertanahan pada Kantor Pertanahan Kabupaten Badung, dan (3) menyusun rekomendasi untuk kebijakan yang harus ditempuh untuk meningkatkan kepuasan pemohon terhadap kualitas pelayanan pertanahan pada Kantor Pertanahan Kabupaten Badung.

\section{METODE}

Penelitian dengan desain cross sectional ini dilakukan di Kantor Pertanahan Kabupaten Badung, Denpasar dengan metode survei. Lokasi ini dipilih karena telah menjalankan sistem loket dengan pelayanan pertanahan berbasis komputer atau komputerisasi kantor pertanahan (KKP). Pertimbangan lainnya yaitu tingkat pertumbuhan ekonomi Kabupaten Badung dipandang relatif tinggi sehingga aspek pelayanan pertanahan memiliki arti strategis bagi kepentingan masyarakat dalam memberikan jaminan kepastian hukum dan perlindungan hukum. Selain itu kondisi sarana dan prasarana kantor yang dianggap kurang memadai turut menjadi pertimbangan dilakukannya penelitian ini. Pengambilan data dalam penelitian dilaksanakan pada bulan Juli 2013.

Populasi dalam penelitian ini adalah pemohon pelayanan pemeliharaan data pendaftaran tanah kegiatan peralihan, pemberian, penegasan dan pengakuan hak atas tanah dan satuan rumah susun subkegiatan jual-beli dan jenis kegiatan hak tanggungan pada tahun 2013 di Kantor Pertanahan Kabupaten Badung. Realisasi data permohonan pelayanan peralihan hak jual beli sebanyak 9.420 dan hak tanggungan sebanyak 10.239 dengan total keseluruhan adalah 19.659. Sampel dalam penelitian ini adalah pemohon yang sedang berada di Kantor Pertanahan Kabupaten Badung dalam rangka pemrosesan pelayanan peralihan hak jual beli dan hak tanggungan dengan teknik convenience sampling. Jumlah contoh dihitung menggunakan rumus Slovin dengan galat 10,0 persen, sehingga diperoleh jumlah sampel pemohon peralihan hak jual beli dan hak tanggungan yang diambil adalah 98 sampel. Untuk mengatasi terjadinya sampling error, selanjutnya jumlah sampel ditambah sehingga menjadi 120 responden.

Data primer dalam penelitian ini merupakan data yang diperoleh langsung dari pemohon melalui pengisian kuesioner mengenai kualitas pelayanan pertanahan di Kantor Pertanahan Kabupaten Badung, Denpasar. Data dan informasi dikumpulkan dengan menggunakan kuesioner yang bersifat tertutup terutama kepada responden yang mengajukan berkas permohonan pelayanan pemeliharaan data pendaftaran tanah kegiatan peralihan hak atas tanah dan satuan rumah susun subkegiatan jual beli dan jenis kegiatan hak tanggungan di Kantor Pertanahan Kabupaten Badung. Untuk dapat melakukan pengukuran tingkat kepuasan pemohon terhadap kualitas pelayanan peralihan hak atas tanah kegiatan jual beli dan pelayanan hak tanggungan pada Kantor Pertanahan Kabupaten Badung, terlebih dahulu disusun indikator-indikator yang telah disesuaikan dengan kondisi pelayanan di bidang pertanahan. Adapun penentuan indikator-indikator didasarkan konsep Zeithaml, Parasuraman, dan Berry (1990) dan memperhatikan lima dimensi utama, yaitu tangible (bukti fisik), reliability (keandalan), responsiveness (daya tanggap), assurance (kepastian), dan empathy (perhatian).

Penilaian kepuasan masyarakat terhadap kualitas pelayanan pertanahan menggunakan metode Servqual yang dikemukakan oleh Zeithaml, Parasuraman, dan Berry (1990) dengan lima dimensi kualitas pelayanan yaitu bukti fisik (tangible), keandalan (reliability), daya tanggap (responsiveness), kepastian (assurance), dan perhatian (empathy). Selanjutnya, kuesioner disusun dengan mengacu pada konsep skala Servqual yang membagi skala dari 1-7 dengan modifikasi penggunaan skala menjadi skala 1-5. Modifikasi ini dilakukan dengan pertimbangan bahwa skala 1-7 terlalu banyak dan menyulitkan responden dalam memberikan penilaian. Skor hasil penilaian responden dari masing-masing indikator yang digunakan untuk mengukur persepsi dan harapan yaitu data yang bersifat kualitatif dan diubah menjadi data yang bersifat kuantitatif dengan cara memberikan bobot penilaian berdasarkan skala Likert dengan skala 1-5. Penilaian bobot untuk kinerja pelayanan peralihan hak atas tanah kegiatan jual beli dan pelayanan hak tanggungan sebagaimana jawaban responden. Penilaian bobot kinerja yang diberikan, yaitu jawaban "sangat baik" diberikan bobot 5, jawaban "baik" diberikan bobot 4, jawaban "cukup baik" diberikan bobot 3, jawaban "kurang baik" diberikan bobot 2, dan jawaban "tidak baik" diberikan bobot 1 .

Berdasarkan hasil perhitungan data yang telah dilakukan uji validitas dan uji reliabilitas instrumen dengan menggunakan metode koefisien korelasi dan Spearman Brown menyebutkan bahwa data sudah valid dan handal. Hasil uji validitas dan uji reliabilitas instrumen diperoleh bahwa kualitas pelayanan 
memiliki nilai Cronbach's alpha masing-masing sebesar 0,92 untuk dimensi tangible (fasilitas fisik), 0,85 untuk dimensi reliabilty (keandalan), 0,88 untuk dimensi responsiveness (daya tanggap), 0,8782 untuk dimensi assurance (kepastian), dan 0,8949 untuk dimensi empathy (perhatian).

Penelitian ini dilakukan menggunakan pendekatan deskriptif dengan metode survei melalui kegiatan pengumpulan data untuk mendapatkan keterangan-keterangan yang jelas mengenai kepuasan pemohon terhadap kualitas pelayanan pertanahan pada Kantor Pertanahan Kabupaten Badung. Fenomena yang terjadi di kalangan pemohon terkait pelayanan pertanahan yang diberikan, akan dijabarkan dalam bentuk kuesioner karakteristik responden (Sari, Suliantoro, \& Windiasari, 2011). Penilaian bobot untuk kinerja pelayanan peralihan hak atas tanah kegiatan jual beli dan pelayanan hak tanggungan sebagaimana jawaban responden.

Adapun analisis data yang digunakan dalam penelitian ini adalah Importance Performance Analysis (IPA), yaitu analisis yang dapat menunjukkan variabel yang dianggap penting oleh pelanggan akan tetapi kurang mendapat perhatian, sehingga kinerja menjadi kurang baik dan pelanggan menjadi tidak puas. Pada Importance Perfomance Analysis (IPA) biasanya ditentukan oleh skor dengan menggunakan skala Likert dengan skala 5. Penilaian bobot harapan yang diinginkan masyarakat sebagaimana jawaban responden. Pada penelitian ini, jawaban "sangat puas" diberi bobot 5, jawaban "puas" diberi bobot 4, jawaban "cukup puas" diberi bobot 3 , jawaban "kurang puas" diberi bobot 2, dan jawaban "tidak puas" diberi bobot 1 untuk setiap kuesioner kinerja dan kuesioner harapan (Waluyo, 2008). Dari pembobotan tersebut, selanjutnya dibuat sumbu mendatar $(X)$ yang diisi dengan skor kinerja, serta dibuat sumbu tegak (Y) yang diisi dengan skor harapan. Garis kedua sumbu tersebut akan membentuk diagram kartesius yang terbagi atas empat bagian yang dibatasi oleh sumbu $X$, sumbu $Y$ dan dua buah garis yang berpotongan tegak lurus pada titik-titik $(X, Y)$, yang mana $X$ merupakan skor rata-rata dari rata-rata kinerja dan $Y$ merupakan skor rata-rata dari rata-rata harapan. Kemudian, indikator-indikator tersebut akan dijabarkan dan dibagi menjadi empat kuadran ke dalam Diagram Kartesius dan dilakukan analisis terhadap indikator yang dianggap memengaruhi kepuasan pemohon yaitu Kuadran I (prioritas utama), Kuadran II (pertahankan prestasi), Kuadran III (prioritas rendah), dan Kuadran IV (berlebihan) (Tjahyadi, 2006).

\section{HASIL}

\section{Karakteristik Responden}

Karakteristik responden yang patut diperhatikan untuk mengetahui persepsi masyarakat terhadap pelayanan pensertifikatan tanah yang diberikan, yaitu jenis kelamin, usia, pendidikan, pekerjaan, luas bidang tanah, pengalaman, jenis pelayanan, jenis sertifikat, waktu penyelesaian sertifikat, dan biaya sertifikat (Suryanti, 2009). Karakteristik responden tersebut mencerminkan kompetensi responden dalam mengukur tingkat kepuasan masyarakat terhadap kualitas pelayanan yang diberikan oleh Kantor Pertanahan.

Berdasarkan hasil penelitian, diperoleh keterangan bahwa jenis kelamin responden sebagian besar adalah laki-laki $(72,5 \%)$ dan sisanya adalah perempuan $(27,5 \%)$. Responden berusia 20-30 tahun (34\%), 31-40 tahun (40\%), 41-50 tahun (14\%), dan sisanya $(12 \%)$ berusia di atas 51 tahun. Tingkat pendidikan formal yang pernah ditempuh responden mulai dari sekolah dasar sampai dengan perguruan tinggi. Responden telah menamatkan SD $(0,83 \%)$, SLTP $(1,67 \%)$, SLTA $(43,33 \%)$, dan perguruan tinggi $(54,17 \%)$. Berdasarkan data tersebut, presentase terbesar responden telah mengikuti tingkat pendidikan formal sampai dengan perguruan tinggi sehingga dapat dikatakan bahwa responden telah mempunyai kecerdasan intelektual yang memadai. Hal ini diperkuat oleh pendapat Aryani dan Rosinta (2010) bahwa kecerdasan intelektual akan diikuti oleh kemampuan sikap dalam menghadapi permasalahan, keterampilan menganalisis, dan mencari alternatif pendekatan masalah.

Jenis pekerjaan responden pada penelitian ini dibagi menjadi empat kelompok. Responden bekerja sebagai PNS/TNI/POLRI (10\%), pegawai swasta $(28,33 \%)$, wiraswasta $(25 \%)$, sedangkan sisanya bekerja sebagai staf PPAT $(36,67 \%)$. Persentase terbesar berada pada kelompok dengan jenis pekerjaan sebagai staf PPAT $(36,67 \%)$, sedangkan persentase terkecil dengan jenis pekerjaan sebagai Pegawai Negeri Sipil (PNS)/TNI/POLRI (10\%).

Berdasarkan tingkat pengalaman dalam mengurus permohonan sertifikat, Hasil penelitian ini menunjukkan bahwa responden yang memiliki pengalaman satu kali dalam mengurus sertifikat $(11,66 \%)$, dua kali 
$(14,17 \%)$, tiga kali $(14,17 \%)$, dan sisanya responden memiliki pengalaman lebih dari tiga kali $(60 \%)$. Berdasarkan tingkat pengalaman yang demikian itu, sebagian besar responden dianggap mempunyai data dan informasi yang cukup untuk dijadikan dasar persepsi mengenai kualitas pelayanan pensertifikatan tanah. Hal tersebut dapat dikatakan bahwa pengalaman seseorang dalam mengurus sertifikat akan memengaruhi persepsinya terhadap kualitas pelayanan pensertifikatan tanah yang diberikan oleh Kantor Pertanahan (Ginting, 2011).

Luas bidang tanah yang dimaksudkan dalam penelitian ini adalah luas bidang tanah yang dimiliki oleh responden atau diberikan kuasa untuk mengurus permohonan sertifikat tanah. Responden yang mengajukan luas bidang tanah yang dimohon $100 \mathrm{~m}^{2}(19,17 \%), 101-300$ $\mathrm{m}^{2}$ (49,17\%), 301-500 m2 (16,66\%), dan lebih besar dari $500 \mathrm{~m}^{2}(15,0 \%)$. Jenis pelayanan yang diutamakan dalam penelitian ini adalah jenis pelayanan dalam rangka kegiatan peralihan hak karena jual beli dan hak tanggungan. Berdasarkan jenis pelayanan pertanahan, pelayanan peralihan hak karena jual beli dan hak tanggungan $(36,67 \%)$, pelayanan penegasan hak $(28,33 \%)$, pelayanan pemberian hak $(24,17 \%)$, dan jenis pelayanan lainnya $(10,83 \%)$, seperti pendaftaran hak pertama kali/pengakuan dan penegasan hak, pemberian Sertifikat Hak Tanggungan, dan Hak Milik Atas Satuan Rumah Susun. Akan tetapi, untuk mempermudah administrasi data pertanahan, maka jumlah realisasi kegiatan pelayanan pada Kantor Pertanahan Kabupaten Badung hasil akhirnya merupakan gabungan dari kedua jenis pelayanan ini, yaitu peralihan hak karena jual beli dan hak tanggungan.

Berdasarkan data responden dalam penelitian ini bahwa berkas permohonan sertifikat hak atas tanah yang sedang dimohon oleh responden untuk diterbitkan sertifikatnya didasarkan atas alas hak yang dimiliki. Berdasarkan data yang diperoleh menunjukkan responden yang mengajukan berkas permohonan untuk Sertifikat Hak Milik (74,17\%), permohonan Sertifikat Hak Guna Bangunan $(20,83 \%)$, Sertifikat Hak Pakai $(4,17 \%)$, dan mengajukan permohonan untuk jenis sertifikat lainnya $(0,83 \%)$, seperti Sertifikat Hak Tanggungan. Jenis permohonan sertifikat yang diinginkan sebagian besar berupa Sertifikat Hak Milik dilanjutkan Sertifikat Hak Guna Bangunan dan Sertifikat Hak Pakai.

Berdasarkan besarnya biaya yang dikeluarkan dalam mengurus sertifikat, ada biaya lain yang harus dibayar oleh responden seperti uang pemasukan, biaya pengukuran dan pemetaan tanah, biaya pemeriksaan tanah sesuai dengan jenis pelayanan menunjukkan responden yang mengeluarkan biaya antara Rp500.000 hingga Rp1.000.000 (22,0\%), Rp1.000.000 hingga Rp2.000.000 (35,0\%), dan lebih dari Rp2.000.000 (43,0\%). Waktu penyelesaian sertifikat adalah lamanya waktu yang diperlukan untuk memproses berkas permohonan hingga terbitnya sertifikat. Jangka waktu yang dibutuhkan untuk penyelesaian sertifikat tanah secara sporadik sangat tergantung dari kejelasan data fisik, kejelasan data yuridis dan harus memenuhi azas publisitas selama 60 hari untuk memberi kesempatan kepada pihak yang berkepentingan dalam mengajukan keberatan. Berdasarkan waktu penyelesaian, sertifikat tanahnya dapat diselesaikan dalam waktu kurang dari 6 bulan (36,67\%), 6-9 bulan (40\%), 9-12 bulan (15\%), dan lebih dari 12 bulan $(8,33 \%)$.

\section{Tingkat Kepuasan Masyarakat terhadap Kualitas Pelayanan Persertifikatan Tanah}

Pada penelitian ini, analisis kesenjangan dilakukan untuk masyarakat yang berperan sebagai pengguna layanan di bidang pertanahan (pelayanan persertifikatan tanah) tanah melalui kegiatan pendaftaran tanah pertama kali secara sporadik. Hal ini dilakukan untuk mengetahui kesenjangan antara kinerja yang dirasakan masyarakat dengan harapan masyarakat sebagai pengguna layanan terhadap 20 indikator kualitas pelayanan pensertifikatan tanah pada Kantor Pertanahan Kabupaten Badung.

Tangibles (fasilitas fisik). Pada dimensi tangibles, indikator yang dinilai meliputi fasilitas fisik kantor $\left(X_{1}\right)$, ruang tunggu pelayanan $\left(X_{2}\right)$, keberadaan loket pelayanan $\left(X_{3}\right)$, dan penampilan pegawai dalam memberikan pelayanan $\left(\mathrm{X}_{4}\right)$. Pengukuran kinerja pada dimensi tangibles ini diperoleh nilai rata-rata sebesar 3,84 dan nilai harapan masyarakat sebesar 4,39 sehingga nilai kesenjangannya adalah $-0,55$. Hal ini menunjukkan bahwa dimensi tangibles tidak memberikan kepuasan pada pemohon/pelanggan.

Reliability atau keandalan. Indikator dimensi reliability meliputi kejelasan persyaratan pelayanan $\left(X_{5}\right)$, kesederhanaan prosedur pelayanan $\left(X_{6}\right)$, kepastian biaya pelayanan $\left(X_{7}\right)$, dan ketepatan waktu penyelesaian sertifikat $\left(X_{8}\right)$. Hasil kinerja terukur pada dimensi reliability (keandalan) mencapai rata- 
rata sebesar 3,83 dengan harapan rata-rata sebesar 4,31. Kesenjangan antara dua variabel tersebut diperoleh sebesar $-0,46$ sehingga hal ini menunjukkan ketidakpuasan.

Responsiveness atau daya tanggap. Dimensi responsiveness yang terdiri atas 4 (empat) indikator, yaitu daya tanggap pegawai terhadap keluhan yang dihadapi masyarakat $\left(X_{9}\right)$, ketepatan dalam memberikan informasi pertanahan $\left(X_{10}\right)$, kecepatan pegawai dalam memberikan pelayanan $\left(X_{11}\right)$, dan ketepatan janji pegawai $\left(X_{12}\right)$. Capaian rata-rata kinerja pada dimensi responsiveness (daya tanggap) sebesar 3,78 dan nilai harapan rata-rata sebesar 4,35. Kesenjangan antara kinerja dan harapan pada dimensi ini sebesar $-0,37$ yang menujukkan ketidakpuasan.

Assurance atau kepastian. Pada dimensi assurance (kepastian) yang terdiri atas indikator kemampuan pegawai dalam memberikan pelayanan $\left(X_{13}\right)$, kejujuran pegawai dalam memberikan pelayanan $\left(X_{14}\right)$, tanggung jawab pegawai dalam pengelolaan berkas permohonan $\left(X_{15}\right)$, dan kesiapan pegawai melayani tepat waktu seseuai ketentuan jam kerja $\left(X_{16}\right)$ menunjukkan nilai rata-rata kinerja sebesar 3,83 dan nilai rata-rata harapan sebesar 4,43 . Hal ini menunjukkan bahwa nilai kesenjangannya negatif sebesar $-0,60$ yang berarti tidak memuaskan.

Empathy atau perhatian. Pengukuran kinerja pada dimensi empathy (perhatian) dengan indikator perhatian pegawai terhadap kebutuhan masyarakat $\left(X_{17}\right)$, keramahan sikap pegawai dalam memberikan pelayanan $\left(X_{18}\right)$, kesabaran pegawai dalam memberikan pelayanan $\left(X_{19}\right)$, dan keikhlasan pegawai dalam memberikan pelayanan $\left(X_{20}\right)$ menghasilkan nilai rata-rata kinerja sebesar 3,79. Adapun nilai rata-rata harapan pada dimensi ini sebesar 4,34 , sehingga nilai kesenjangannya sebesar $-0,55$ yang menunjukkan ketidakpuasan terhadap pelayanan. Berdasarkan nilai rata-rata kinerja $(3,82)$ dan harapan $(4,36)$ dari keempat dimensi kualitas pelayanan pensertifikatan tersebut memiliki kesenjangan sebesar -0,55. Hal ini menunjukkan bahwa kualitas pelayanan persetifikatan tidak memuaskan.

Selanjutnya, analisis kinerja dan kepentingan (harapan) juga dilakukan dengan membandingkan rata-rata kinerja dengan rata-rata harapan pada seluruh indikator kualitas pelayanan yang diteliti. Indikator pada Kuadran I dan Kuadran II disajikan pada Tabel 1, sedangkan Tabel 2 menunjukkan indikator pada Kuadran III dan Kuadran IV.
Tabel 1 Indikator kualitas pelayanan berdasarkan kinerja dan kepentingan

\begin{tabular}{|c|c|c|c|c|}
\hline & Indikator & Kinerja & $\begin{array}{l}\text { Kepen- } \\
\text { tingan }\end{array}$ & $\begin{array}{c}\text { Kuadra } \\
n\end{array}$ \\
\hline$X_{1}$ & $\begin{array}{l}\text { Fasilitas fisik } \\
\text { kantor }\end{array}$ & 3,73 & 4,37 & $\begin{array}{c}\text { I } \\
\text { (Prioritas }\end{array}$ \\
\hline$X_{11}$ & $\begin{array}{l}\text { Kecepatan } \\
\text { pegawai dalam } \\
\text { memberikan } \\
\text { pelayanan }\end{array}$ & 3,81 & 4,45 & Utama) \\
\hline$X_{12}$ & $\begin{array}{l}\text { Ketepatan janji } \\
\text { pegawai }\end{array}$ & 3,78 & 4,44 & \\
\hline$X_{14}$ & $\begin{array}{l}\text { Kejujuran } \\
\text { pegawai dalam } \\
\text { memberikan } \\
\text { pelayanan }\end{array}$ & 3,78 & 4,39 & \\
\hline$X_{18}$ & $\begin{array}{l}\text { Keramahan } \\
\text { sikap pegawai } \\
\text { dalam } \\
\text { memberikan } \\
\text { pelayanan }\end{array}$ & 3,77 & 4,38 & \\
\hline $\mathrm{X}_{2}$ & $\begin{array}{l}\text { Ruang tunggu } \\
\text { pelayanan }\end{array}$ & 3,88 & 4,36 & $\begin{array}{c}\text { II } \\
\text { Pertahan- }\end{array}$ \\
\hline$x_{3}$ & $\begin{array}{l}\text { Keberadaan } \\
\text { loket } \\
\text { pelayanan }\end{array}$ & 3,91 & 4,44 & $\begin{array}{c}\text { kan } \\
\text { Prestasi) }\end{array}$ \\
\hline$X_{4}$ & $\begin{array}{l}\text { Penampilan } \\
\text { pegawai dalam } \\
\text { memberikan } \\
\text { pelayanan }\end{array}$ & 3,85 & 4,39 & \\
\hline$X_{13}$ & $\begin{array}{l}\text { Kemampuan } \\
\text { pegawai dalam } \\
\text { memberikan } \\
\text { pelayanan }\end{array}$ & 3,83 & 4,44 & \\
\hline$X_{15}$ & $\begin{array}{l}\text { Tanggung } \\
\text { jawab pegawai } \\
\text { dalam } \\
\text { pengelolaan } \\
\text { berkas } \\
\text { permohonan }\end{array}$ & 3,83 & 4,44 & \\
\hline$X_{16}$ & $\begin{array}{l}\text { kesiapan } \\
\text { pegawai } \\
\text { melayani tepat } \\
\text { waktu sesuai } \\
\text { ketentuan jam } \\
\text { kerja }\end{array}$ & 3,88 & 4,44 & \\
\hline
\end{tabular}

Kuadran I yang menjadi sasaran prioritas utama perbaikan adalah fasilitas fisik kantor $\left(X_{1}\right)$, kecepatan pegawai dalam memberikan pelayanan $\left(X_{11}\right)$, ketepatan janji pegawai $\left(X_{12}\right)$, kejujuran pegawai dalam memberikan pelayanan $\left(X_{14}\right)$, dan keramahan sikap pegawai dalam memberikan pelayanan $\left(X_{18}\right)$. Pada Kuadran II yang merupakan indikator-indikator yang kinerjanya dapat dipertahankan, yaitu ruang tunggu pelayanan $\left(X_{2}\right)$, keberadaan loket pelayanan $\left(X_{3}\right)$, penampilan pegawai dalam memberikan pelayanan $\left(X_{4}\right)$, kemampuan pegawai dalam memberikan pelayanan $\left(X_{13}\right)$, tanggung jawab pegawai dalam pengelolaan berkas permohonan $\left(X_{15}\right)$, dan kesiapan 
pegawai melayani tepat waktu sesuai ketentuan jam kerja $\left(\mathrm{X}_{16}\right)$.

Sementara itu, pada Kuadran III memuat indikator kualitas pelayanan yang memiliki nilai harapan dan kinerja yang relatif rendah. Adapun indikatornya yaitu kepastian biaya pelayanan $\left(X_{7}\right)$, ketepatan waktu penyelesaian sertifikat $\left(X_{8}\right)$, daya tanggap pegawai terhadap keluhan masyarakat $\left(X_{9}\right)$, ketepatan dalam memberikan informasi pertanahan $\left(X_{10}\right)$, perhatian pegawai dalam memberikan pelayanan $\left(\mathrm{X}_{17}\right)$, dan kesabaran pegawai dalam memberikan pelayanan $\left(\mathrm{X}_{19}\right)$.

Adapun kuadran IV merupakan indikator kualitas pelayanan yang memiliki nilai harapan yang relatif rendah sedangkan kinerjanya dinilai relatif tinggi, sehingga dirasakan berlebihan oleh pemohon. Indikator yang masuk dalam kuadran IV yaitu kejelasan persyaratan pelayanan $\left(X_{5}\right)$, kesederhanaan prosedur pelayanan $\left(X_{6}\right)$, dan keikhlasan pegawai dalam memberikan pelayanan $\left(\mathrm{X}_{20}\right)$.

Tabel 2 Indikator kualitas pelayanan berdasarkan kinerja dan kepentingan

\begin{tabular}{|c|c|c|c|c|}
\hline & Indikator & $\begin{array}{c}\text { Kine } \\
\text { rja }\end{array}$ & $\begin{array}{l}\text { Kepen- } \\
\text { tingan }\end{array}$ & Kuadran \\
\hline$X_{7}$ & $\begin{array}{l}\text { Kepastian biaya } \\
\text { pelayanan }\end{array}$ & 3,81 & 4,28 & $\begin{array}{c}\text { III } \\
\text { (Prioritas }\end{array}$ \\
\hline$X_{8}$ & $\begin{array}{l}\text { Ketepatan } \\
\text { waktu } \\
\text { penyelesaian } \\
\text { sertifikat }\end{array}$ & 3,78 & 4,31 & Rendah) \\
\hline$X_{9}$ & $\begin{array}{l}\text { Daya tanggap } \\
\text { pegawai } \\
\text { terhadap keluhan } \\
\text { masyarakat }\end{array}$ & 3,74 & 4,24 & \\
\hline $\mathrm{X}_{10}$ & $\begin{array}{l}\text { Ketepatan } \\
\text { dalam } \\
\text { memberikan } \\
\text { informasi } \\
\text { pertanahan }\end{array}$ & 3,78 & 4,28 & \\
\hline$X_{17}$ & $\begin{array}{l}\text { Perhatian } \\
\text { pegawai dalam } \\
\text { memberikan } \\
\text { pelayanan }\end{array}$ & 3,78 & 4,35 & \\
\hline$X_{19}$ & $\begin{array}{l}\text { Kesabaran } \\
\text { pegawai dalam } \\
\text { memberikan } \\
\text { pelayanan }\end{array}$ & 3,78 & 4,32 & \\
\hline$X_{5}$ & $\begin{array}{l}\text { Kejelasan } \\
\text { persyaratan } \\
\text { pelayanan }\end{array}$ & 3,93 & 4,35 & $\begin{array}{l}\text { IV } \\
\text { (Berlebih- } \\
\text { an) }\end{array}$ \\
\hline$X_{6}$ & $\begin{array}{l}\text { Kesederhanaan } \\
\text { prosedur } \\
\text { pelayanan }\end{array}$ & 3,89 & 4,33 & \\
\hline$X_{20}$ & $\begin{array}{l}\text { Keikhlasan } \\
\text { pegawai dalam } \\
\text { memberikan } \\
\text { pelayanan }\end{array}$ & 3,83 & 4,30 & \\
\hline
\end{tabular}

\section{PEMBAHASAN}

Pelayanan pada bidang pertanahan merupakan bentuk pelayanan publik yang banyak mendapatkan sorotan dari masyarakat agar segera memperbaiki kinerjanya. Kantor Pertanahan Kabupaten/Kota sebagai ujung tombak pelayanan pertanahan di daerah dinilai memiliki kinerja yang masih rendah serta terkesan lambat, sulit, mahal, tidak pasti, dan berbelit-belit, sehingga dianggap perlu direformasi agar pelayanannya lebih baik, adil, transparan, keberpihakan kepada masyarakat ekonomi lemah, dan mengutamakan hak-hak adat termasuk hak ulayat (Adnan, 2007).

Penelitian ini dilakukan dengan mengukur dan menganalisis indikator-indikator kinerja pelayanan pada lima dimensi, yaitu tangible, reliability, responsiveness, assurance, dan empathy. Dimensi tangible meliputi kesiapan dari sarana dan prasarana pendukung seperti sarana fisik, komputerisasi, ruang tunggu, penampilan petugas yang rapi dan materi yang berhubungan dengan pelayanan. Dimensi realibility meliputi keandalan untuk menyediakan pelayanan yang terpercaya terhadap pemohon dan memberikan layanan akurat sejak pertama kali serta menyampaikan sesuai dengan waktu yang disepakati. Dimensi responsiveness berkaitan dengan kesanggupan untuk membantu dan menyediakan pelayanan secara cepat, tepat serta tanggap terhadap pemohon. Dimensi assurance berkaitan dengan sikap pegawai dalam meyakinkan kepercayaan pemohon, menciptakan rasa aman bagi para pemohon, mempunyai kemampuan untuk menyelesaikan tugas-tugas dengan baik. Sementara itu, dimensi empathy berhubungan dengan pemahaman terhadap masalah yang dialami pemohon, tindakantindakan demi kepentingan pemohon, serta memberikan perhatian kepada pemohon.

Hasil analisis kesenjangan menunjukkan tingkat kepuasan masyarakat untuk setiap dimensi memiliki nilai negatif yang berarti kinerja yang terukur lebih kecil daripada ukuran harapan masyarakat/pemohon. Dengan kata lain, masyarakat tidak puas terhadap kinerja pelayanan pertanahan yang diberikan oleh Kantor Pertanahan Kabupaten Badung.

Berdasarkan hasil penelitian, dimensi fasiitas fisik (tangibles) untuk keberadaan loket pelayanan memiliki nilai kesenjangan paling besar karena keberadaan loket saat ini belum dapat berjalan efektif dan efisien, sehingga sangat besar pengaruhnya terhadap tingkat kepuasan masyarakat atas kualitas pelayanan 
Peralihan Hak Atas Tanah Kegiatan Jual Beli dan Pelayanan Hak Tanggungan. Keberadaan loket pelayanan dimaksudkan agar berkas permohonan yang masuk ke Kantor Pertanahan dapat diproses lebih cepat dengan menggunakan sistem loket pelayanan yang tersedia dengan tetap memperhatikan pencapaian sasaran pelayanan. Dimensi keandalan (reliability) untuk ketepatan waktu penyelesaian sertifikat memiliki nilai kesenjangan paling besar, karena waktu penyelesaian sertifikat yang telah ditentukan tidak sesuai dengan kenyataan yang ada. Untuk itu masyarakat berharap agar ketepatan waktu penyelesaian sertifikat hak atas tanah dapat diwujudkan sesuai dengan ketentuan yang berlaku.

Adapun dimensi daya tanggap atau responsiveness untuk ketepatan janji pegawai mendapat nilai kesenjangan paling besar dari indikator lainnya. Ketepatan janji pegawai merupakan suatu kesanggupan pegawai untuk memberikan pelayanan sebaik mungkin kepada masyarakat. Dimensi kepastian (assurance) untuk kejujuran pegawai dalam memberikan pelayanan dan tanggung jawab pegawai dalam pengelolaan berkas permohonan memiliki kesenjangan paling besar dibandingkan dengan indikator lainnya. Hal ini disebabkan tidak tertibnya penyimpanan berkas membuat pengelolaan berkas permohonan menjadi sulit, sehingga menyebabkan kerja dalam manajemen data menjadi terhambat dan pelayanan kepada masyarakat pun menjadi kurang baik. Dimensi perhatian (empathy) dinilai tidak memuaskan karena perhatian pegawai lebih banyak diberikan untuk melayani staf PPAT dibandingkan melayani masyarakat pada umumnya, kurang ramahnya pegawai akibat tingkat kesibukan yang tinggi, kesabaran pegawai dalam menghadapi pemohon kurang memenuhi harapan, dan mental pegawai dalam melayani kurang ikhlas.

Berdasarkan uraian analisis masing-masing dimensi kualitas pelayanan pensertifikatan tanah, dapat disimpulkan bahwa secara keseluruhan kualitas pelayanan pensertifikatan tanah yang diberikan oleh Kantor Pertanahan Kabupaten Badung belum memenuhi kepuasan masyarakat. Hal ini ditunjukkan oleh selisih perolehan antara skor rata-rata kinerja sebesar 3,82 dengan skor rata-rata harapan sebesar 4,34 sehingga diperoleh skor rata-rata kesenjangan negatif sebesar $-0,55$. Kesenjangan negatif ini memberi arti bahwa kualitas pelayanan pensertifikatan tanah yang telah diberikan oleh Kantor Pertanahan Kabupaten Badung secara keseluruhan belum memberikan kepuasan bagi masyarakat.
Kesenjangan negatif tersebut terjadi karena ketidaksesuaian antara kinerja mengenai pelayanan yang dirasakan dengan pelayanan yang diharapkan oleh masyarakat. Oleh karena itu kualitas pelayanan pensertifikatan tanah harus dapat ditingkatkan agar memberikan kepuasan kepada masyarakat sebagai pengguna layanan. Adapun indikator-indikator yang memiliki kesenjangan di bawah skor rata-rata kualitas pelayanan pensertifikatan tanah adalah indikator fasilitas fisik kantor $\left(X_{1}\right)$, kecepatan pegawai dalam memberikan pelayanan $\left(X_{11}\right)$, ketepatan janji pegawai $\left(X_{12}\right)$, kemampuan pegawai dalam memberikan pelayanan $\left(X_{13}\right)$, kejujuran pegawai dalam memberikan layanan $\left(X_{14}\right)$, tanggung jawab pegawai dalam pengelolaan berkas permohonan $\left(X_{15}\right)$, kesiapan pegawai melayani tepat waktu sesuai ketentuan jam kerja $\left(X_{16}\right)$, dan keikhlasan pegawai dalam memberikan pelayanan $\left(\mathrm{X}_{20}\right)$.

Analisis kinerja dan kepentingan atau umumnya disebut sebagai harapan terhadap kualitas pelayanan pensertifikatan tanah juga dilakukan dengan membandingkan rata-rata kinerja dengan rata-rata harapan pada seluruh indikator kualitas pelayanan yang diteliti (Ardiansyah, 2015). Perbandingan tersebut selanjutnya dicantumkan ke dalam Diagram Kartesius untuk mengetahui indikator kualitas pelayanan yang diprioritaskan untuk segera diperbaiki kualitas pelayanannya.

Dengan menggunakan analisis Importance Perfomance Analysis (IPA) tersebut dapat diperoleh gambaran penilaian masyarakat terhadap kualitas pelayanan pensertifikatan tanah pada Kantor Pertanahan Kabupaten Badung, sehingga diperoleh hasil penilaian masyarakat secara keseluruhan terhadap indikator-indikator kualitas pelayanan persertifikatan tanah yang dapat dikelompokkan menjadi empat kuadran. Adapun garis pembagi dalam analisis tersebut adalah nilai rata-rata dari skor rata-rata kinerja yaitu sebesar 3,82 dan nilai rata-rata dari skor rata-rata kepentingan sebesar 4,36.

Adapun yang menjadi prioritas utama perbaikan adalah indikator-indikator yang berada pada kuadran I. Kuadran I menunjukkan indikator-indikator kualitas pelayanan yang memiliki nilai kepentingan relatif tinggi sedangkan nilai kinerjanya relatif rendah (Prasetyani, 2009). Dengan demikian indikator kualitas pelayanan pensertifikatan tanah pada Kantor Pertanahan Kabupaten Badung yang berada dalam kuadran ini, kinerjanya harus ditingkatkan dengan melakukan perbaikan secara berkesinambungan. 
Indikator $\left(\mathrm{X}_{1}\right)$ fasilitas fisik kantor yang tersedia mencakup toilet, musholla untuk tempat beribadat, anjungan informasi mandiri untuk mengetahui keberadaan berkas permohonan, papan pengumuman untuk informasi dan tempat parkir kendaraan bermotor. Berdasarkan nilai kesenjangan yang terjadi, masyarakat merasakan ketidakpuasan terhadap fasilitas fisik kantor yang tersedia dalam mendukung kelancaran pelayanan pensertifikatan tanah. Ketidakpuasan ini ditunjukkan oleh fasilitas fisik kantor yang belum sesuai dengan harapan masyarakat dalam menunjang kelancaran pelayanan di bidang pertanahan. Fasilitas fisik yang tersedia saat ini kurang dijaga kebersihannya terutama toilet, sehingga masyarakat sedikit terganggu apabila datang berkunjung ke Kantor Pertanahan dengan kondisi fisik yang kurang bersih. Selain itu, pemeliharaan fasilitas fisik lainnya tidak dilakukan secara rutin dan seringkali tidak berfungsi dengan baik, seperti anjungan informasi mandiri yang sangat berguna untuk melakukan pengecekan berkas permohonan yang sedang diproses. Kemudian pemanfaatan papan pengumuman yang tidak mengikuti perkembangan informasi terbaru dan melakukan penyesuaian dengan kebutuhan informasi pelayanan pertanahan yang diperlukan oleh masyarakat. Hal tersebut di atas diperkuat dengan pernyataan bahwa jasa merupakan kinerja dan tidak dapat dirasakan sebagaimana halnya barang, maka pelanggan cenderung memperhatikan fakta-fakta tangibles yang berkaitan dengan jasa sebagai bukti kualitas. Bukti-bukti kualitas jasa berupa fasilitas fisik jasa seperti gedung, penampilan pemberi jasa, perlengkapan dan peralatan yang digunakan dan lain-lain dapat pula menciptakan kinerja tertentu terhadap perusahaan jasa.

Indikator $\left(\mathrm{X}_{11}\right)$ kecepatan pegawai dalam memberikan pelayanan dinilai tidak memuaskan. Ketidakpuasan masyarakat tercermin dari lambatnya pelayanan yang diberikan kepada masyarakat. Sebagai penyelenggara pelayanan publik di bidang pertanahan, Kantor Pertanahan berkewajiban memberikan pelayanan yang dapat diakses secara mudah, murah, dan cepat. Dengan menerapkan prinsip cepat dan tepat dalam bekerja, maka dapat membuat efisiensi terhadap waktu yang tersedia untuk pelayanan pensertifikatan hak atas tanah. Prinsip bekerja seperti inilah yang masih kurang dirasakan oleh masyarakat atas pelayanan pertanahan yang diberikan sehingga menimbulkan kekecewaan bagi masyarakat.

Indikator $\left(X_{12}\right)$ ketepatan janji pegawai dinilai tidak memuaskan. Penilaian ini didasarkan atas tingkat kepuasan masyarakat terhadap ketapatan janji pegawai dalam memberikan pelayanan seringkali menimbulkan kekecewaan, karena masyarakat sudah bosan dengan janji-janji yang diberikan namun seringkali diingkari, yang akhirnya dapat menyebabkan hilangnya rasa kepercayaan terhadap kinerja aparat pertanahan. Padahal masyarakat yang datang ke Kantor Pertanahan untuk mengurus permohonan sertifikat hak atas tanah memiliki kesibukannya masing-masing, sehingga dengan ketidaktepatan janji yang diberikan oleh pegawai pertanahan membuat masyarakat terpaksa mengalami kerugian waktu, tenaga dan biaya. Sebenarnya, untuk menghindari janji-janji yang diberikan kepada masyarakat, sebaiknya setiap pegawai dalam bekerja dapat menggunakan waktu kerja semaksimal mungkin, karena dengan bekerja maksimal akan menghindari terjadinya penumpukan pekerjaan pada hari-hari sebelumnya.

Pada indikator kejujuran pegawai dalam memberikan pelayanan $\left(X_{14}\right)$, responden memberikan nilai tidak memuaskan, artinya kepuasan masyarakat terhadap kejujuran pegawai dalam memberikan pelayanan belum terpenuhi. Ketidakpuasan masyarakat tercermin dari sikap pegawai yang dinilai belum berperilaku sesuai dengan tanggung jawab dan kewenangan yang diberikan, serta tidak transparan dalam memberikan pelayanan kepada masyarakat.

Kejujuran pegawai dalam memberikan pelayanan kepada masyarakat sangat diperlukan karena dengan kejujuran pegawai lebih bertanggung jawab terhadap pekerjaannya, lebih berani dalam bertindak dan berani mengatakan ia ataupun tidak dengan tetap berpegang teguh terhadap ketentuan yang berlaku, sehingga tidak akan merugikan masyarakat yang sedang memerlukan pelayanan (Hadjam, 2001). Selain itu, kejujuran akan memberikan dampak terhadap kepercayaan seseorang. Kejujuran pegawai dalam memberikan penjelasan kepada masyarakat menjadi sangat penting. Masyarakat secara umum belum melihat penjelasanpenjelasan yang telah disampaikan oleh pegawai pertanahan telah sesuai dengan keadaan yang sebenarnya. Ratminto dan Winarsih (2005), mengatakan bahwa kejujuran sangat diperlukan karena akan mendorong pegawai untuk melaksanakan tugas sesuai amanah yang diberikan. Sikap jujur akan membentengi seseorang dari melakukan halhal yang tidak sesuai dengan nilai-nilai yang dianutnya. 
Indikator keramahan sikap pegawai dalam memberikan pelayanan $\left(\mathrm{X}_{18}\right)$ dinilai tidak memuaskan. Ketidakpuasan masyarakat tercermin dari penilaian intensitas pekerjaan pegawai yang semakin meningkat sehingga mengurangi keramahan sikap dari pegawai dalam memberikan pelayanan. Kondisi seperti ini menyebabkan kebutuhan masyarakat untuk dilayani tidak terpenuhi, apalagi sebagian masyarakat belum mengerti dan memahami tata cara pelayanan di bidang pertanahan. Keramahan pegawai dalam memberikan pelayanan adalah merupakan wujud dari penghormatan terhadap masyarakat. Keramahan sikap pegawai dalam memberikan pelayanan kepada masyarakat terkait dengan sifat dan sikap pribadi pegawai yang bersangkutan. Namun demikian, dengan tingkat kesibukan yang tinggi diharapkan tidak menjadi penyebab hilangnya sikap ramah pegawai kepada masyarakat yang datang.

Untuk rekomendasi peningkatan perbaikan layanan (kinerja), pelaksanaan pelayanan harus dapat diukur. Oleh karena itu dapat ditetapkan suatu standar baik dalam hal waktu yang diperlukan maupun hasilnya, agar supaya hasil akhir memuaskan pada pihak-pihak yang mendapatkan pelayanan (Aprilian, 2010). Menyikapi hal tersebut, pada tanggal 20 Juli 1998 Menteri Negara Agraria/Kepala Badan Pertanahan Nasional mengeluarkan Instruksi Menteri Negara Agraria/Kepala BPN Nomor 3 Tahun 1998 tentang Peningkatan Efisiensi dan Kualitas Pelayanan Masyarakat di Bidang Pertanahan. Lebih lanjut diterbitkan Peraturan Pemerintah Nomor 13 Tahun 2010 tentang Jenis dan Tarif Atas Jenis Penerimaan Negara Bukan Pajak yang Berlaku pada Badan Pertanahan Nasional, Keputusan Kepala BPN Nomor 1 Tahun 2005 tentang Standar Prosedur Operasi Pengaturan dan Pelayanan di lingkungan Badan Pertanahan Nasional, Peraturan Kepala Badan Pertanahan Nasional Nomor 1 tahun 2010 tentang Standar Pelayanan dan Pengaturan Pertanahan di Lingkungan Badan Pertanahan Nasional dan kebijakan lainnya untuk mendorong pelayanan pertanahan, khususnya Kantor Pertanahan Kabupaten/Kota.

Standar pelayanan publik tersebut merupakan ukuran atau persyaratan dasar yang harus dipenuhi dalam penyelenggaraan pelayanan publik dan wajib ditaati oleh pemberi pelayanan (pemerintah) dan atau pengguna pelayanan (masyarakat) sehingga masyarakat penerima pelayanan publik merasakan adanya nilai yang tinggi atas pelayanan tersebut. Cakupan standar pelayanan publik yang harus ditetapkan sekurang-kurangnya meliputi prosedur pelayanan, waktu penyelesaian, biaya pelayanan, produk pelayanan, sarana dan prasarana, serta kompetensi petugas pemberi pelayanan (Wijaya, 2007).

Pelaksanaan standar pelayanan publik dapat dilihat kualitas pelayanan yang diberikan kepada pengguna pelayanan (masyarakat). Kualitas dapat digunakan untuk menilai atau menentukan tingkat penyesuaian suatu hal terhadap persyaratan atau spesifikasinya (Arief, 2011). Bila persyaratan atau spesifikasinya itu terpenuhi berarti kualitas sesuatu hal yang dimaksud dapat dikatakan baik, sebaliknya jika persyaratan tidak terpenuhi maka dapat dikatakan tidak baik. Selain itu kualitas memiliki hubungan yang erat dengan kepuasan pelanggan. Kepuasan pelanggan dapat digambarkan secara singkat sebagai berikut: Kepuasan $=$ Persepsi - Ekspetasi (Afifuddin, 2009). Persepsi adalah evaluasi pemohon terhadap pelayanan setelah diberikan. Ekspetasi adalah harapan sebelum memperoleh pelayanan. Kepuasan akan dicapai bila persepsi sama atau lebih besar daripada ekspetasi. Ketidakpuasan terjadi bila persepsi lebih rendah daripada ekspetasi.

Kantor Pertanahan sebagai ujung tombak pelayanan yang merupakan operasionalisasi dari seluruh kebijakan yang dirumuskan oleh BPN, maka sebagai pihak yang dilayani, pemohon dapat memberikan penilaian secara obyektif berdasarkan kenyataan pelayanan yang telah diberikan. Dengan penilaian obyektif ini, diharapkan data yang diperoleh akan mencerminkan kondisi dan masalah yang ada di kantor pertanahan. Selanjutnya, analisa yang dilakukan dapat menghasilkan keluaran yang akurat dan rekomendasi yang tepat sasaran.

\section{SIMPULAN DAN SARAN}

Berdasarkan uraian pembahasan dan analisis masing-masing dimensi kualitas pelayanan pensertifikatan tanah, khususnya pelayanan Peralihan Hak Atas Tanah Kegiatan Jual Beli dan Pelayanan Hak Tanggungan di atas, dapat disimpulkan bahwa secara keseluruhan kualitas pelayanan pensertifikatan tanah yang diberikan oleh Kantor Pertanahan Kabupaten Badung belum memenuhi kepuasan masyarakat. Selanjutnya, prioritas peningkatan yang direkomendasikan untuk meningkatkan kepuasan masyarakat terhadap kualitas pelayanan pensertifikatan tanah pada Kantor Pertanahan Kabupaten Badung yang bertujuan menyediakan informasi bagi pembuat kebijakan untuk dijadikan bahan pertimbangan dalam 
memecahkan masalah yang terjadi terhadap pelaksanaan kebijakan meliputi ketepatan waktu penyelesaian sertifikat, keikhlasan pegawai dalam memberikan pelayanan, kesiapan pegawai, melayani tepat waktu sesuai ketentuan jam kerja, keberadaan loket layanan pelayanan, ketepatan janji pegawai, kepastian biaya pelayanan, kesederhanaan prosedur pelayanan, dan kemampuan pegawai dalam memberikan prosedur pelayanan.

\section{DAFTAR PUSTAKA}

Adnan, A. (2007). Studi penyusunan indikator kinerja pelayanan pertanahan: dalam rangka kegiatan pendaftaran tanah untuk pertama Kali. Makalah disampaikan dalam kegiatan desiminasi/Seminar Hasil-hasil Penelitian Puslitbang BPN-RI, tanggal 28-12-2007, Bogor.

Afifuddin, M. (2009). Analisis pengaruh kualitas pelayanan terhadap kepuasan pelanggan pada PT. Persero Angkasa Pura 1 di Bandar Udara Ahmad Yani Semarang (Tesis). Sekolah Pascasarjana Universitas Terbuka, Jakarta.

Aprilian, T. (2010). Analisis produktivitas tenaga kerja pada pekerjaan struktur rangka atap baja (studi kasus proyek pembangunan Rumah Sakit dr. Moewardi, Surakarta Jawa Tengah) (Tesis). Universitas Sebelas Maret, Surakarta.

Ardiansyah, A. (2015). Perjanjian pengikatan jual beli hak atas tanah berdasarkan akta notaris di Kecamatan Kandis (Tesis). Universitas Islam Negeri Sultan Syarif Kasim, Riau.

Arief, M. (2007). Pemasaran jasa dan kualitas pelayanan: Bagaimana mengelola kualitas pelayanan agar memuaskan pelanggan. Malang, ID: Bayumedia Puslitbang.

Arief, M. (2011). Kualitas pelayanan publik di Bandara Internasional Sultan Hasanuddin Makassar (Studi kasus pelayanan jasa penumpang). Academica - Jurnal IImiah Fakultas Sosial dan IImu Politik Universitas Tadulako, 3(2), 729 -740.

Aryani, D., \& Rosinta, F. (2010). pengaruh kualitas layanan terhadap kepuasan pelanggan dalam membentuk loyalitas pelanggan. bisnis \& birokrasi. Jurnal IImu Administrasi dan Organisasi, MeiAgustus 2010, 114-126.

Ginting, D. (2011). Reformasi hukum tanah dalam rangka perlindungan hak atas tanah perorangan dan penanam modal dalam bidang agrobisnis. Jurnal Hukum, $1,63-82$.

Hadjam, M. N. R. (2001). Efektivitas pelayanan prima sebagai upaya meningkatkan pelayanan di Rumah Sakit (Perspektif Psikologi). Jurnal Psikologi Universitas Gadjah Mada, 28(2), 105-115.

[KPK] Komisi Pemberantasan Korupsi (2013). Indeks integritas sektor publik tahun 2013. Pusat Hubungan Masyarakat, Jakarta.

Musanto, T. (2004). Pengaruh kualitas pelayanan dan harga terhadap kepuasan pelanggan. Jurnal Manajemen dan Kewirausahaan, 6(2).

Prasetyani, N. (2009). Analisis kinerja pelayanan publik perusahaan daerah air minum (PDAM) Kabupaten Demak (Tesis). Program Pascasarjana Universitas Diponegoro, Semarang.

Ratminto. \& Winarsih, A. S. (2005). Manajemen pelayanan: Pengembangan model konseptual, penerapan citizen's charter dan standar pelayanan minimal. Yogyakarta, ID: Penerbit Pustaka Pelajar.

Sari, D. P., Suliantoro, H., \& Windiasari, R. (2011). Analisis atribut-atribut yang memengaruhi tingkat kepuasan pelanggan telepon rumah (fixed wireline) menggunakan metode analisis diskriminan (Studi Kasus di PT. Telkom Kandatel Semarang).J@ti Undip,6(2).

Suharno, (2002). Persepsi masyarakat terhadap pensertifikatan tanah (kasus di Desa Girikerto Kecamatan Turi Kabupaten Sleman). Jurnal Pertanahan, 2, Juli 2002. Sekolah Tinggi Pertanahan Nasional.

Sukirno, N., Mulyanto, B., \& Hakim, D. B. (2015) Analisis kesenjangan pada pelayanan pendaftaran tanah pertama kali di kantor pertanahan Kota Bekasi. Jur. IIm Kel. \& Kons., 8(2). 106-114.

Suryanti, S. (2009). Kinerja aparat pelayanan pada kantor pertanahan Kota Semarang. (Tesis). Program Pascasarjana Universitas Diponegoro. Semarang.

Tjahyadi, R. A. (2006). Brand trust dalam konteks loyalitas merek: Perak karakteristik merek, karakteristik perusahaan, dan karakteristik hubungan pelangganmerek. Jurnal Manajemen, 6(1).

Waluyo, M. (2008). Pengaruh kualitas pelayanan terhadap standar pelayanan 
terpadu dan kepuasan pelanggan di PT. PLN (PERSERO) UPJ $X$ Surabaya. Jurnal Penelitian IImu Teknik, 8(2).

Widjaja, M., Wijaya, S., \& Jokom, R. (2007). Analisis penilaian konsumen terhadap ekuitas merek coffee shops di Surabaya. Jurnal Manajemen Perhotelan, 3(2), 89101.

Wijaya, S. W. (2007). Budaya organisasi dan efektifitas penerapan e-government.
Makalah disampaikan Seminar Nasional Aplikasi Teknologi Informasi 2007 (SNATI 2007). 16 Juni 2007. Yogyakarta.

Zeithaml, V., Parasuraman, A., \& Berry, L. L. (1990). Delivering Quality of Service Balancing Customer Perception and Expectation. New York, US: The Free Press: A Division of Macmillan, Inc. 